DOI: https://doi.org/10.47405/mjssh.v6i5.774

\begin{tabular}{|c|c|}
\hline 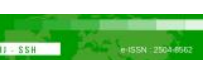 & Malaysian Journal of Social Sciences and Humanities (MJSSH) \\
\hline 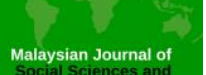 & Volume 6, Issue 5, May 2021 \\
\hline (MJ-sSH) & e-ISSN : 2504-8562 \\
\hline & $\begin{array}{l}\text { Journal home page: } \\
\text { www.msocialsciences.com }\end{array}$ \\
\hline
\end{tabular}

\title{
Issues and Challenges in Teaching Secondary School Quantum Physics with Integrated STEM Education in Malaysia
}

\author{
Laurah Markus $^{1}$, Stephanie Sungkim ${ }^{1}$, Mohd. Zaki Bin Ishak ${ }^{1}$ \\ 1Faculty of Psychology and Education, Universiti Malaysia Sabah (UMS) \\ Correspondence: Laurah Markus (dp1911008t@student.ums.edu.my)
}

\begin{abstract}
The emphasis on STEM education in the physics curriculum moves toward addressing the $21^{\text {st }}$-century demands, but its implementation is fraught with issues and challenges. This paper exposes teachers' and students' concerns and problems with integrated STEM education implementation and relates them to the anticipated problem in quantum physics $(\mathrm{QP})$ learning and facilitation $(\mathrm{L} \& \mathrm{~F})$ in secondary school. The QP L\&F challenges include the odd ontological worldview and abstractness of concepts, which have created serious misconceptions among teachers and students. A solution is proposed to address this difficulty, including applying an interactive simulation and a hands-on experiment. This paper also proposes a theoretical framework for developing an instructional module to cater to meaningful QP learning with integrated STEM elements. The proposed theoretical framework has several advantages, including guidance in planning an instructional module applicable to classroom activities and explaining the topic using an inquiry-based learning (IBL) approach with learning activities coordinated using the $5 \mathrm{E}$ Instructional Model. Nonetheless, further research is necessary to study the instructional module's development, usability, and L\&F effectiveness in the classroom.
\end{abstract}

Keywords: integrated stem education, quantum physics, learning and facilitation, secondary school

\section{Introduction}

In an era of rapid technological advancement, Malaysia is striving for a developed nation to create a scientific, progressive, creative, and prudent society that is crucial in developing future scientific and technological civilizations (Academy of Sciences Malaysia, 2017; MOE, 2018; MOSTI, 2013, 2017). The Ministry of Education believed that these qualities and literacy in Science, Technology, Engineering, and Mathematics (STEM) must be developed to achieve this goal (Farihah Mohd Jamel et al., 2019; Maruthai, 2019; MOE, 2018; MOSTI, 2017).

Along with the aspirations, the Secondary School Curriculum Standards (KSSM) was enacted, replacing the Secondary School Integrated Curriculum $(K B S M)$ to meet the new policy requirements under the Malaysia Education Blueprint (PPPM) 2013-2025 to ensure that the secondary school curriculum is comparable to international standards (Farihah Mohd Jamel et al., 2019; MOE, 2018). Hence, with a holistic approach, the Curriculum and Assessment Standards Document (DSKP) is created to guide teachers in implementing learning and facilitation $(\mathrm{L} \& \mathrm{~F})$ in the classroom. 
The physics DSKP highlighted student-centred learning approaches to develop $21^{\text {st }}$ century skills and train students to be competent in the rapid technological growth era and the Industrial Revolution (IR) 4.0 challenges (MOE, 2018). Apart from that, the QP topic is included in the curriculum (MOE, 2018) to expose students to modern physics' perspective and its contribution to the advancement of modern technology such as computers, smartphones, lasers, Global Positioning System (GPS), and Magnetic Resonance Imaging (MRI) (Henriksen et al., 2014; Krijtenburg-Lewerissa et al., 2018; Park et al., 2019). QP has been highlighted as an important topic for secondary school (Krijtenburg-Lewerissa et al., 2018; Moraga-Calderón et al., 2020; Polatdemir et al., 2004) as a fundamental and modern aspect of physics (Moraga-Calderón et al., 2020) that forms the cognitive basis for a proper interpretation of microscopic matter (Kalkanis et al., 2003), which has gained social prominence (Mashhadi \& Woolnough, 1996; Michelini et al., 2002; Schleich et al., 2016; Sutrini et al., 2019).

With the inclusion of QP in the physics curriculum, integrated STEM education can be a good strategy to create active and meaningful QP learning as STEM education is the most highlighted in the current education setting (Amelia \& Lilia Halim, 2019; Bunyamin, 2015; Shahali et al., 2015), whereby the MOE strives in empowering STEM education through national transformation agenda which is now in the second wave (2016-2020) phase to cultivate public interest and awareness of STEM through campaigns and collaboration with relevant agencies (Amelia \& Lilia Halim, 2019).

\section{Literature Review}

\section{Issues pertaining to integrated STEM Education implementation}

Malaysia depends on knowledgeable workers in driving the economy and handling the uncertainties in the IR 4.0 era (Academy of Sciences Malaysia, 2017). However, generating a workforce for STEMrelated and technology-based future jobs is challenging as studies show that the number of qualified workers has been declining over the years (Academy of Sciences Malaysia, 2015, 2017; Shahali et al., 2015). The current analysis shows that students' interest in the STEM field has decreased, whereby only $44 \%$ of students took STEM compared to $49 \%$ in 2012, equivalent to an average reduction of about 6,000 students per year (MOE, 2019). With this analysis, it is perceived that the current rate of student entry into STEM studies at the higher and secondary levels would be insufficient in supplying qualified staff to meet the aspired projections or develop the expected knowledge-driven, value-added economy (Academy of Sciences Malaysia, 2017).

Meanwhile, the major national examinations' quality is only average, making pedagogies questionable in addressing the millennial learning trend (Academy of Sciences Malaysia, 2017). This issue may be related to the lack of competencies among teachers in conducting integrated STEM education, as the survey conducted by the Academy of Science Malaysia (2017) shows that nearly 47\% of STEM secondary school teachers did not receive STEM training since its introduction to school. However, Malaysia is new to integrated STEM education (Maruthai, 2019), and there is no official curriculum yet (Amelia \& Lilia Halim, 2019). The STEM education implementation guide (MOE, 2016b, 2016a) does not provide specific STEM performance standards apart from the DSKP for each subject. By far, the learning specification streaming system for students is branded as a STEM package (Edy Hafizan et al., 2017; MOE, 2016b), which is similar to Martín-Páez et al. (2019) study in terms of STEM elements integration, where learning involves integrating conceptual, procedural, and attitudinal through a group of STEM skills with a real-world problem-solving approach.

Another ongoing issue in the Malaysian education system is the workload of teachers, where their duties involve not only preparing and planning for L\&F but also clerical tasks such as data entry, inventory, students' data management, and a continuous engagement with school events that are scheduled and coordinated throughout the year, which restrain teachers from preparing for meaningful lessons (Abdullah et al., 2017; Nur Farhana Ramli \& Othman Talib, 2017; Siew et al., 2015). It was worsening when teachers rushed to finish the syllabus within the timeline to prepare students for the examinations, 
especially the national examination, Sijil Pelajaran Malaysia (SPM), which had caused burnout among teachers (Nur Farhana Ramli \& Othman Talib, 2017).

Apart from that, students have been trained and drilled to answer questions that are already set with a familiar pattern in an examination-oriented education system, which encourages memorization (Ro, 2018). For instance, this method may help students pass and score in the examination but does not add up to STEM skills, such as real-world problem-solving, critical thinking, and science process skills (Chin et al., 2019; Porcaro, 2011). Thus, promoting and nurturing an integrated STEM education culture should be emphasized to provide students with opportunities to develop their potential. Simultaneously, teachers must possess the knowledge and skills necessary to have a positive impact on students (Pearson, 2017).

\section{Challenges in teaching Quantum Physics with integrated STEM Education}

Science, technology, and Innovation (STI) are essential keys to national economic growth and social progress, which brought STEM education into the main agenda in education transformation (Academy of Sciences Malaysia, 2015, 2017; MOSTI, 2017). The rapid advancement in this field instigates the education system to evolve, and thus, teachers must progress too to be useful and effective in executing the education transformation (Abdullah et al., 2017; Academy of Sciences Malaysia, 2017; MOE, 2016a). In realizing the aspiration, teachers are advocated to conduct instructional strategies that can engage students in challenging, enjoyable, and meaningful learning activities to attract more science stream students (MOE, 2016b, 2018). In this manner, teachers need to be well-equipped with pedagogical skills that include integrated STEM education to meet the 21st-century demands (Abdullah et al., 2017; Wan Norhasma \& Nurahimah, 2019).

However, integrating STEM education is difficult because traditional instructional approaches have presented STEM disciplines separately, with a distinct and inconsistent collection of facts and skills (English, 2016; Pearson, 2017). Teachers are expected to bridge the boundaries between STEM disciplines in this situation (Shahali et al., 2015). Besides, they must understand the intent of integrated STEM education and clearly demonstrate how it can be accomplished while ensuring that all STEM elements are integrated with learning activities that help students master the necessary skills (Pearson, 2017).

In physics KSSM particularly, teachers are expected to implement the integrated STEM education approach in learning and facilitation (L\&F) (MOE, 2018) and expose students to real-life problemsolving, community, and environmental issues (Edy Hafizan et al., 2017; MOE, 2016b). The inadequacy of skills in this area made it challenging for teachers to pursue, which had caused inconsistent teaching and learning quality (Academy of Sciences Malaysia, 2017).

For QP learning with integrated STEM education, it is anticipated to be more challenging because this newly added topic is different from classical physics and has a long unclear interpretation in history (Angelo et al., 2014). Due to the confusing QP ontology, it is challenging for teachers to transfer the knowledge (Ab Rahman \& Phang, 2012; Bungum et al., 2015; Shi, 2013; Stadermann \& Goedhart, 2020). Besides, teachers must master the QP fundamental concepts with some mathematical formalism before transferring them to students (Angelo et al., 2014). In particular, what challenges a teacher is how to teach the wave-particle duality and the photoelectric effect experiment effectively. In these topics, teachers need to guide students to understand the particle nature of light and the concept of a photon (McKagan et al., 2009; Supurwoko et al., 2017) and address the gap between classical and quantum concepts of waves, particles, and uncertainty by emphasizing their differences in the classical and quantum world (Rodriguez, 2018).

While QP is challenging due to its nature, integrated STEM education, on the other hand, challenges teachers in carrying out appropriate learning activities with QP knowledge. Thus, the ability to integrate STEM disciplines and elements is required, which develops students' capacity to comprehend the QP concept and acquire skills by applying the concepts and adding attitudinal values through their learning experience. 
The current textbook does not specify instruction or activity that involves STEM activities for the QP topic (Chuan et al., 2020). Teachers with limited information about integrated STEM education may become dependent on a textbook, following a brief instruction of the suggested activities which is not paying sufficient attention to essential skills such as problem-solving, application of the principle, interpreting and predicting (Academy of Sciences Malaysia, 2015; Toma \& Greca, 2018). Insufficient knowledge, especially in engineering and technology discipline, also demotivated teachers from pursuing integrated STEM education, thus adhering to their teaching routine (EL-Deghaidy et al., 2017; White, 2014).

In rural and suburban areas where schools lack facilities such as internet connection, laboratory and educational resources, teachers may struggle to implement integrated STEM education (Academy of Sciences Malaysia, 2017; Siew et al., 2015). In this situation, it is anticipated that it will be more challenging in QP learning as this topic is better learned with technology application to visualize the abstract concepts (Kohnle et al., 2012; McKagan et al., 2008; G. Ravaioli, 2019).

\section{The anticipated difficulties in Quantum Physics learning}

QP in the physics curriculum introduces the fundamental concepts, which comprises the quantum theory of light, wave-particle duality, photoelectric effect, and Einstein photoelectric effect (MOE, 2018). This topic concentrates more on conceptual understanding than complicated mathematics formulation to cater to its suitability (Chuan et al., 2020). Since QP is new in the physics curriculum, local research on instructional strategies is hardly found in search engines. However, numerous researches have been done overseas, which is crucial in informing about the ongoing trends and issues in QP teaching and learning.

In contrasting QP from classical physics (Krijtenburg-Lewerissa et al., 2017), Mashhadi and Woolnough (1999) explained that classical physics basically rely on macroscopic observations and concepts are chosen for intuitive visualization. On the other hand, quantum phenomena are dominant at the microscopic level, which has led to the intuitive violation of concepts. For example, the entity located in space is called a particle, an intuitive concept that has presumably passed from the macroscopic to the microscopic (Mashhadi \& Woolnough, 1999). Another example is the quantization of energy, a fascinating aspect that significantly differentiates QP from the classical view but is confusing to grasp (Cuppari et al., 1997).

Although QP often intrigues young students (Bøe et al., 2018; Bungum et al., 2015; Johansson et al., 2018; Myhrehagen \& Bungum, 2016), many researchers and educators reported that this topic is difficult for students to understand (Dutt, 2011; Malgieri et al., 2017), which classified by Malgieri et al. (2017) as conceptual difficulties because they are intuitive, which require qualitative reasoning and mental models of the students. Due to a different paradigm, even though students have a strong knowledge of classical physics, they became novices when QP was introduced, and the knowledge structure had to be gradually established (Singh \& Marshman, 2015). This situation is common as teachers also encountered the same problem (Kızılcık \& Yavaş, 2016). Additionally, the quantum world is difficult for students to explore independently, and the majority of misconceptions are formed after the learning experience due to their inability to apply it to everyday practice (Testa et al., 2020). Wave-particle duality, photon, electron, the uncertainty principle, and photoelectric effect are among the problematic concepts often mentioned by researchers (Dutt, 2011; Krijtenburg-Lewerissa et al., 2017; Olsen, 2002).

Other difficulties reported were concerning students' visualization of the experiment results, which involves a challenging mathematical calculation to interpret an experiment (Cataloglu \& Robinett, 2002; Mashhadi \& Woolnough, 1999). Besides, its epistemology is somehow illogical and abstract, disconnected to everyday living, has no direct experience with the phenomenon, and often relying on simplified abstract models to develop conception (Cataloglu, 2002; Dangur et al., 2014; McKagan et al., 2008). As a result, the nature of QP had caused serious misconceptions among students. Furthermore, the topic is new to secondary school students and is disconnected from classical physics (Hadzidaki et al., 2000). 
As seen in the wave-particle duality conception, students developed misconceptions mostly impacted by other areas of knowledge, such as common sense and classical physics (Olsen, 2002), where students' conceptual frameworks were overlapped and mixed with classical physics and quantum mechanics. For example, the Newtonian-based deterministic worldview imposes their newfound knowledge (Hadzidaki et al., 2000; Kalkanis et al., 2003; Stadermann \& Goedhart, 2020).

Student's misconceptions are also caused by a direct implication of teaching (Olsen, 2002). Traditional teaching often employs pedagogical analogies or metaphors that refer to daily life images, such as electron clouds for the atomic spatial location of bound electrons or bright spherical balls model to represent the quantum entity. This mental image, which is also shown in the textbook, is confusing when students try to relate to the QP concept, which they never encountered (Kalkanis et al., 2003; KrijtenburgLewerissa et al., 2017). Other studies also have shown that the appearance of the wave-like behavior of electrons distributed as merely bright spots had caused the students to think that the wave-like behavior is a cloud of spattered charge (Müller \& Wiesner, 2002). These mental images or models were wrongly understood as students failed to understand the atomic model's energy quantization concept (Taber, 2005).

The atomic Bohr model and the development of instructional physics models that modeled electrons as negatively charged tiny billiard balls also influenced student perception of QP (Stadermann et al., 2019; Stadermann \& Goedhart, 2020). Students tend to explain electrons using a classical planetary model, as shown in the Bohr atom model (Stadermann \& Goedhart, 2020), and the representation students make in the classroom often corresponds to everyday experiences materials (Kalkanis et al., 2003). While in the double-slit experiment for electrons, the interference pattern formed shows electrons are a wave and not as miniature billiard balls or particles (Sayer et al., 2017). The electrons representation is confusing to students as they lack of a useful framework to contrast explainable physical laws (Stadermann \& Goedhart, 2020). The QP ontological supposedly correspond to what could be termed as 'quantum objects' with specific characteristics. When traditional teaching methods use a mechanical analogy, it has led to particles being treated as ordinary material objects without discriminating the ontological conditions (Kalkanis et al., 2003).

As discussed, most of the issues that influence students' difficulties in understanding QP are the quantum theories' ontological and epistemological views. Malaysian secondary school students may experience these difficulties, and they need to be addressed to eliminate the causes of misconception in understanding QP concepts. In the study of creating better learning of QP's epistemology and cognitive approach, Ravaioli et al. (2018) emphasize visualization, comparability, and ontology in instructional strategy, which are discussed further in the next section.

\section{Proposed solution and Theoretical Framework}

More research has been conducted to minimize QP instructional difficulties (see: Bungum et al., 2015; Kohnle, 2010; McKagan et al., 2007, 2008; Ravaioli, 2019; Singh, 2008; Sokolowski, 2013; Supurwoko et al., 2017). It is also highlighted that an alternative to the teacher-centered learning strategy, a conventional strategy (Kunnath, 2017; Marshman \& Singh, 2015; Zollman, 1999) known as direct instruction (Mansyur \& Darsikin, 2016), is needed as it was seen that the traditional strategy is not sufficient in helping students understand abstract concepts like QP (Gonen, 2006; Hubber, 2006; Sayer et al., 2017)) and had caused students to become passive learners (Francisco, 2013).

As aforementioned, QP is indeed a tough and elusive topic, difficult to understand than classical physics. Hence, it requires a specific approach to tackle the problems (Habibbulloh, 2019; López-Incera \& Dür, 2019; Krijtenburg-Lewerissa et al., 2017; McKagan et al., 2009; Stadermann \& Goedhart, 2020). Integrated STEM education philosophy in empowering cohesive teaching and learning paradigm may encourage and arouse students' interest in QP with real-life contexts and common technological applications (Stadermann et al., 2019). 
Many studies have used the real-world situation in QP learning activities and agreed that it could enhance students' conceptual understanding (Escalada et al., 2004; McKagan et al., 2009; Michelini et al., 2004; Tarng et al., 2018). The use of instructional technology that utilizes computer-based technology in pedagogical instruction, including interactive simulation, and videos, can be advantageous for abstract concepts (White, 2014). In particular, a hands-on activity called Hallwachs' experiments (Ravaioli, 2019) and the photoelectric effect simulation, an interactive virtual lab from PhET (Physics Education Technology) (McKagan et al., 2009) can be utilized in facilitating the students' conception of QP. Several studies have used and recommended these materials as practical tools that can promote inquiry learning in challenging classical physics reasoning by contrasting quantum theory with the classical view (McKagan et al., 2009; Ravaioli, 2019). Hence, these materials can be studied thoroughly to utilize them optimally in classroom activities.

It was seen that the photoelectric effect experiment could improve QP teaching by minimizing the abstractness and facilitate the interpretation of phenomena that could increase students' motivation (Didiş et al., 2014; Michelini et al., 2014). By comparing the classical hypothesis, empirical results, and quantum explanation, this experiment could compare classical physics with the quantum view and anticipate the teaching problem (Asikainen \& Hirvonen, 2009).

However, learning gains depend on how a teacher delivers the lesson (Kamsi et al., 2019; Zaher Atwa et al., 2016). For students to have meaningful learning, it requires a well-planned strategy, considering essential aspects that contribute to achieving the required goals that parallel to the current education setting. Additionally, instructional materials with a student-centered learning approach like inquirybased learning can be employed to stimulate students' interest in QP, which is also suited to the STEM learning environment (Murphy et al., 2019; Satanassi et al., 2018). Developmental research can be carried out to develop an instructional module that facilitates teachers to overcome the issues and challenges in QP L\&F.

The inquiry-based learning strategy has been recommended by scholars (Bybee, 2013; Thibaut et al., 2018) to promotes active learning and support the use of authentic, real-world problems (Thibaut et al., 2018) in adapting to the current learning ecosystem (Anealka Aziz, 2018). As the education setting evolves, it opens more spaces for empirical research in instructional development. Thus, a theoretical framework is proposed in developing an instructional module for secondary school QP with an integrated STEM education approach in addressing the anticipated challenges in the L\&F of the QP topic.

The proposed theoretical framework is divided into three sub-sections that are guided by the design and development research (Richey \& Klein, 2007), as shown in Figure 1. The needs analysis study is guided by Mckillip's Discrepancy Model (Chedi, 2017; McKillip, 1987; Mohd Paris Saleh \& Saedah Siraj, 2016; Yaakob, 2016) to discover and identify the needs for a QP instructional module in secondary school. With the information in phase 1, the instructional module for secondary school QP with an integrated STEM education approach is designed and developed with five theories and models to support and guide the design and development phase. The constructivism theory (Dewey, 1938; Harasim \& Harasim, 2018; Soloway et al., 1996) is the foundation of the instructional and learning approach with the TABA Model (Aydin et al., 2017; Portillo et al., 2020; Taba, 1962) as a guide in structuring and organizing the components and elements in the instructional module that comprises inquiry-based learning and integrated STEM education strategy for the L\&F of the Wave-particle duality concept as the content knowledge, and the 5E Instructional Model as a guide in structuring the learning activities. In the final stage of the research, the TUP model (Bednarik, 2002; Bednarik et al., 2004) guides the instructional module prototype's usability evaluation for experienced teachers to evaluate and validate the technological, usability and pedagogical use in assisting QP L\&F. 
DOI: https://doi.org/10.47405/mjssh.v6i5.774

Figure 1: Author's suggestion of the theoretical framework in developing an instructional module for secondary school QP with integrated STEM education

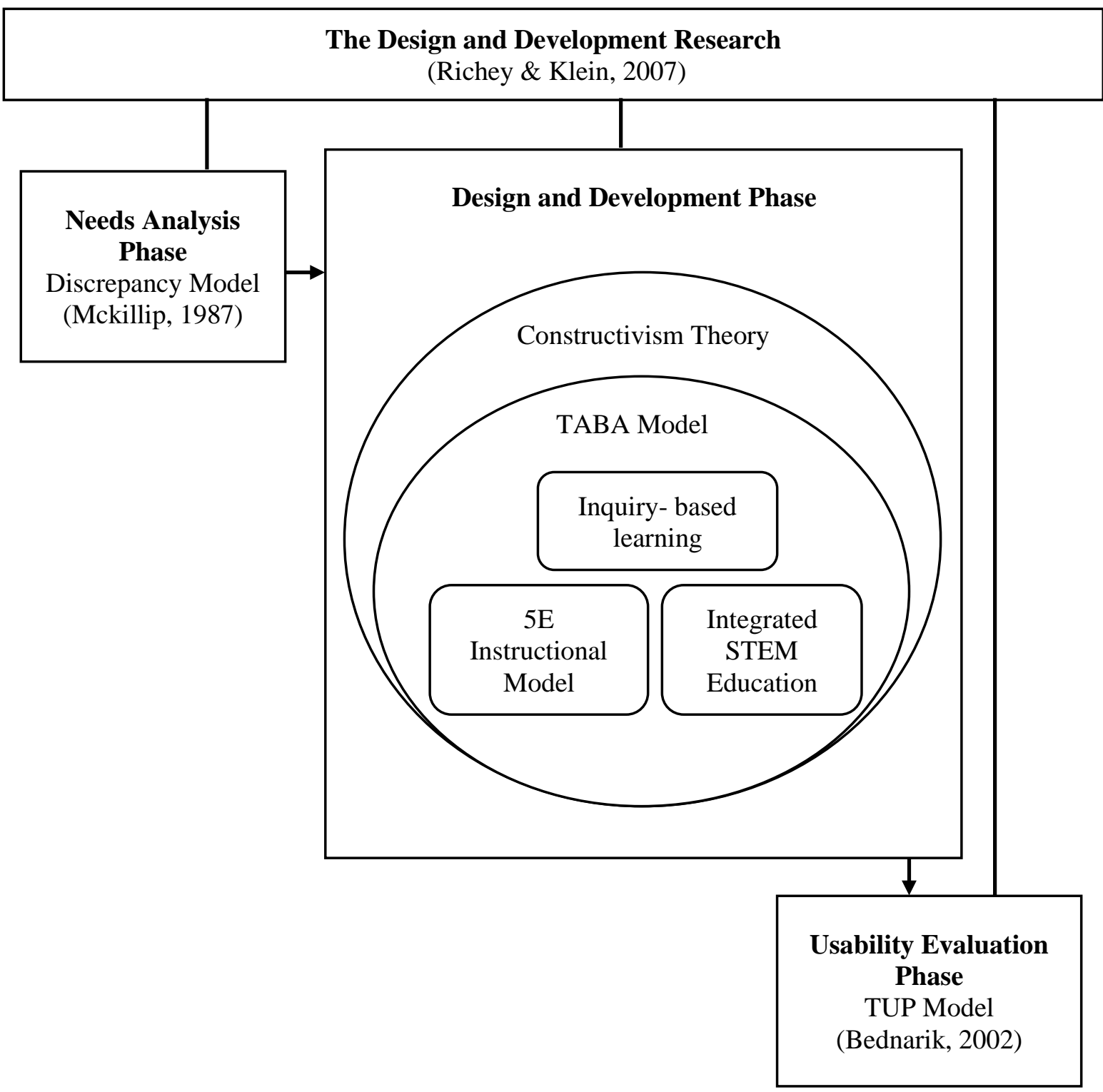

\section{Discussion and Implication}

Reviews of the corresponding literature have highlighted several gaps in developing students' understanding of $\mathrm{QP}$ in the physics curriculum related to the anticipated learning difficulties and instructional challenges, as well as issues and challenges pertaining to integrated STEM education. The proposed solution and the theoretical framework embrace a constructivist perspective, supporting inquiry-based learning strategies that emphasize active learning in promoting a meaningful learning experience. The instructional module's theoretical framework aims to provide student-centered activities, with the teacher's role as a facilitator. In this regard, an instructional module can be used as an alternative to the traditional approach, encouraging teamwork, critical thinking, innovation, and communication in the classroom while being consistent with integrated STEM education strategies.

This concept paper intends to provide insight into discovering alternatives or solutions to problems by exposing the issues and challenges in implementing integrated STEM education. Besides, the difficulties 
in QP L\&F inform researchers and teachers about what to expect in carrying out QP lessons and provide insight in dealing with the issues. By exploring the integrated STEM education approach and strategies, it is possible to incorporate them into QP L\&F to develop an instructional module or learning materials. Nonetheless, further research is necessary to investigate these instructional strategies' effects on student's cognitive and affective learning outcomes.

\section{Conclusion}

To summarise, the present paper has presented issues concerning the implementation of integrated STEM education, challenges in teaching QP with integrated STEM education, and anticipated difficulties in QP learning. Based on previous literature, techniques such as applying interactive simulation and a handson experiment with inquiry-based learning strategy and the integrated STEM education strategy were suggested. A theoretical framework for developing an instructional module for secondary school QP with integrated STEM education provides ideas for the developmental research field. It is hoped that this paper benefit researchers and educators in finding a solution to ensure successful teaching and learning capable of providing a potential solution and insight into the future study.

\section{References}

Ab Rahman, N. F., \& Phang, F. A. (2012). Exploring the epistemic equity among physics teachers' agency to support inclusivity in learning Ab Rahman, N. F.

Abdullah, A. H., Hussin, R. H. S. R., Rahman, S. N. S. A., Hamzah, M. H., Kohar, U. H. A., \& Juhazren Junaidi. (2017). Teachers' Readiness in Implementing Science, Technology, Engineering and Mathematics (STEM) Education from the Cognitive, Affective and Behavioural Aspects. IEEE International Conference on Teaching, Assessment and Learning for Engineering (TALE), December, 6-12.

Academy of Sciences Malaysia. (2015). Science Outlook action towards vision. In BMC Public Health (Vol. 5, Issue 1). Ministry of Science, Technology And Innovation.

Academy of Sciences Malaysia. (2017). Science Outlook Converging Towards Progressive Malaysia 2050. Ministry of Science, Technology And Innovation.

Amelia, N., \& Lilia Halim. (2019). Cabaran Pengintegrasian Pendidikan STEM Dalam Kurikulum Malaysia. Seminar Wacana Pendidikan, September, 1-10.

Anealka Aziz. (2018). Education 4.0 Made Simple: Ideas For Teaching. International Journal of Education and Literacy Studies, 6(3), 92.

Angelo, M. D., Garuccio, A., Romano, F., Lena, F. Di, Incecco, M. D., Moro, R., Regano, A., \& Scarcelli, G. (2014). Frontiers of Fundamental Physics and Physics Education Research. 145, 407416. https://doi.org/10.1007/978-3-319-00297-2

Asikainen, M. A., \& Hirvonen, P. E. (2009). A study of pre- and inservice physics teachers' understanding of photoelectric phenomenon as part of the development of a research-based quantum physics course. American Journal of Physics. https://doi.org/10.1119/1.3129093

Aydın, B., Melek, M., Alan, B., \& Sağlam, S. (2017). Combining the old and the new: Designing a curriculum based on the taba model and the global scale of English. Dil ve Dilbilimi Çalışmaları Dergisi, 13(1), 304-320.

Bednarik, R. (2002). Evaluation of Educational Environments. The TUP Model. University of Joensuu.

Bednarik, R., Gerdt, P., Miraftabi, R., \& Tukiainen, M. (2004). Development of the TUP model Evaluating educational software. Proceedings - IEEE International Conference on Advanced Learning Technologies, ICALT 2004, 699-701. https://doi.org/10.1109/ICALT.2004.1357627

Bøe, M. V., Henriksen, E. K., \& Angell, C. (2018). Actual versus implied physics students: How students from traditional physics classrooms related to an innovative approach to quantum physics. Science Education, 102(4), 649-667. https://doi.org/10.1002/sce.21339

Bungum, B., Henriksen, E. K., Angell, C., Tellefsen, C. W., \& Bøe, M. V. (2015). ReleQuant Improving teaching and learning in quantum physics through educational design research. Nordic Studies in Science Education, 11(2), 153. https://doi.org/10.5617/nordina.2043 
Bunyamin, M. A. H. (2015). Pendidikan STEM Bersepadu : Perspektif Global , Perkembangan Semasa di Malaysia, dan Langkah Kehadapan. The Bulletin of the Johor Association of Science and Mathematics Education, 25(1)(November 2015), 1-6.

Bybee, R. W. (2013). The case for STEM Education Challenges and Opportunities (J. Horak, A. Cooke, $\&$ W. Rubin (eds.)). NSTA Press.

Cataloglu, E., \& Robinett, R. W. (2002). Testing the development of student conceptual and visualization understanding in quantum mechanics through the undergraduate career. American Journal of Physics. https://doi.org/10.1119/1.1405509

Cataloglu, Erdat. (2002). Development and Validation of an Achievement Test in Introductory Quantum Mechanics: the Quantum Mechanics Visualization Instrument (Qmvi). May, 196.

Chedi, J. M. (2017). A Preliminary Review on Needs Analysis and Delphi Technique : Effective Tools for Data Collection. Journal of Asian Vocational Education and Training, 10(2011), 44-52.

Chin, H., Thien, L. M., \& Chew, C. M. (2019). The Reforms of National Assessments in Malaysian Education System. Journal of Nusantara Studies (JONUS), 4(1), 93-111. https://doi.org/http://dx.doi.org/10.24200/jonus.vol4iss1pp93-111

Chuan, K. K., Choy, C. S., Kasron, Nor Rizah Bongkek, J., \& Mohd Khairul Anuar; Pradeep Kumar Chakrabarty. (2020). Chapter 7 Quantum Physics. In Norazlina Binti Hamat; Kanageaswarry Thangarajan (Ed.), Dual Language Program Physics Form 5 KSSM (pp. 222-247). Penerbit Bestari Sdn. Bhd.

Cuppari, A., Rinaudo, G., Robutti, O., \& Violino, P. (1997). Gradual introduction of some aspects of quantum mechanics in a high school curriculum. Physics Education, 32(5), 302-308. https://doi.org/10.1088/0031-9120/32/5/012

Dangur, V., Avargil, S., Peskin, U., \& Dori, Y. J. (2014). Learning Quantum Chemistry via Visualconceptual Approach: Students' Bidirectional Textual and Visual Understanding Vered. Chemistry Education Research and Practice, 15(3), 297-310.

Dewey, J. (1938). Logic: The Theory of Inquiry. Henry Holt. https://doi.org/10.5040/9781472547262.ch-005

Didiş, N., EryIlmaz, A., \& Erkoç, Ş. (2014). Investigating students' mental models about the quantization of light, energy, and angular momentum. Physical Review Special Topics - Physics Education Research, 10(2), 1-28. https://doi.org/10.1103/PhysRevSTPER.10.020127

Dutt, A. (2011). Making the transition from classical to quantum physics. Teaching Science, 57(4), 3336.

Edy Hafizan, M. S., Ihsan, I., \& Lilia, H. (2017). STEM education in Malaysia: Policy, trajectories and initiatives. Policy Trajectories and Initiatives in STEM Education, 122-133.

EL-Deghaidy, H., Mansour, N., Alzaghibi, M., \& Alhammad, K. (2017). Context of STEM Integration in Schools: Views from In-service Science Teachers. Eurasia Journal of Mathematics, Science and Technology Education, 13(6), 2459-2484. https://doi.org/10.12973/eurasia.2017.01235a

English, L. D. (2016). STEM education K-12: perspectives on integration. International Journal of STEM Education, 3(1), 1-8. https://doi.org/10.1186/s40594-016-0036-1

Escalada, L., Rebekki, N. S., \& Zollman, D. A. (2004). Student Explorations of Quantum Effects in LEDs and Luninescent Devices. The Physics Teachers, 42(3), 173-179. https://doi.org/https://doi.org/10.1119/1.1664385

Farihah Mohd Jamel, Mohd Norawi Ali, \& Nur Jahan Ahmad. (2019). The needs analysis in gamebased STEM module development for KSSM science teachers. International Journal of Recent Technology and Engineering, 8(3), 6622-6628. https://doi.org/10.35940/ijrte.C5655.098319

Francisco, A. R. L. (2013). On Constructivism. Journal of Chemical Information and Modeling, 53(9), 1689-1699. https://doi.org/10.1017/CBO9781107415324.004

Gonen, S. (2006). Effects of concept maps, semantic networks and computer simulations on students' understanding of quantum physics. Journal of Science Education, 7(2), 95-98.

Habibbulloh, M. (2019). Effectiveness of the guided discovery model based virtual lab PhET toward mastery students' concept on topic Photoelectric Effect. Science Education and Application Journal. https://doi.org/10.30736/seaj.v1i1.100

Hadzidaki, P., Kalkanis, G., \& Stavrou, D. (2000). Quantum mechanics: A systemic component of the modern physics paradigm. Physics Education, 35(6), 386-392. https://doi.org/10.1088/00319120/35/6/302

Harasim, L., \& Harasim, L. (2018). Constructivist Learning Theory. In Learning Theory and Online 
Technologies. https://doi.org/10.4324/9781315716831-5

Henriksen, E. K., Bungum, B., Angell, C., Tellefsen, C. W., Frågåt, T., \& Bøe, M. V. (2014). Relativity, quantum physics and philosophy in the upper secondary curriculum: Challenges, opportunities and proposed approaches. Physics Education. https://doi.org/10.1088/0031-9120/49/6/678

Hubber, P. (2006). Year 12 students' mental models of the nature of light. Research in Science Education, 36(4), 419-439. https://doi.org/10.1007/s11165-006-9013-x

Johansson, A., Andersson, S., Salminen-Karlsson, M., \& Elmgren, M. (2018). "Shut up and calculate": the available discursive positions in quantum physics courses. Cultural Studies of Science Education, 13(1), 205-226. https://doi.org/10.1007/s11422-016-9742-8

Kalkanis, G., Hadzidaki, P., \& Stavrou, D. (2003). An Instructional Model for a Radical Conceptual Change Towards Quantum Mechanics Concepts. Science Education, 87(2), 257-280. https://doi.org/10.1002/sce.10033

Kamsi, N. S., Radin Firdaus, R. B., Abdul Razak, F. D., \& Ridha Siregar, M. (2019). Realizing Industry 4.0 Through STEM Education: But Why STEM Is Not Preferred? IOP Conference Series: Materials Science and Engineering, 506(1), 0-7. https://doi.org/10.1088/1757-899X/506/1/012005

Kızılcık, H. Ş., \& Yavaş, P. Ü. (2016). Pre-service Physics Teachers' Opinions about the Difficulties in Understanding Introductory Quantum Physics Topics. Journal of Education and Training Studies, 5(1), 101. https://doi.org/10.11114/jets.v5i1.2012

Kohnle, A. (2010). Developing and evaluating animations for teaching quantum mechanics concepts. European Journal of Physics, 31(6), 1441-1455. https://doi.org/10.1088/0143-0807/31/6/010

Kohnle, A., Cassettari, D., Edwards, T. J., Ferguson, C., Gillies, A. D., Hooley, C. A., Korolkova, N., Llama, J., \& Sinclair, B. D. (2012). A new multimedia resource for teaching quantum mechanics concepts. American Journal of Physics, 80(2), 148-153. https://doi.org/10.1119/1.3657800

Krijtenburg-Lewerissa, K., Pol, H. J., Brinkman, A., \& Joolingen, W. R. Van. (2018). Key topics for quantum mechanics at secondary schools: a Delphi study into expert opinions. International Journal of Science Education, 41(3). https://doi.org/10.1080/09500693.2018.1550273

Krijtenburg-Lewerissa, K., Pol, H. J., Brinkman, A., \& Van Joolingen, W. R. (2017). Insights into teaching quantum mechanics in secondary and lower undergraduate education. Physical Review Physics Education Research, 13(1). https://doi.org/10.1103/PhysRevPhysEducRes.13.010109

López-Incera, A., \& Dür, W. (2019). Entangle me! A game to demonstrate the principles of quantum mechanics. American Journal of Physics, 87(2), 95-101. https://doi.org/10.1119/1.5086275

Malgieri, M., Onorato, P., \& Ambrosis, A. De. (2017). Test on the effectiveness of the sum over paths approach in favoring the construction of an integrated knowledge of quantum physics in high school. Physical Review Physics Education Research, 13(1), 010101-1-25. https://doi.org/10.1103/PhysRevPhysEducRes.13.010101

Mansyur, J., \& Darsikin, D. (2016). Enhancing Direct Instruction on Introductory Physics for Supporting Students' Mental-Modeling Ability. International Education Studies, 9(6), 32. https://doi.org/10.5539/ies.v9n6p32

Marshman, E., \& Singh, C. (2015). Framework for understanding the patterns of student difficulties in quantum mechanics. Physical Review Special Topics - Physics Education Research. https://doi.org/10.1103/PhysRevSTPER.11.020119

Martín-Páez, T., Aguilera, D., Perales-Palacios, F. J., \& Vílchez-González, J. M. (2019). What are we talking about when we talk about STEM education? A review of literature. Science Education, 103(4), 799-822. https://doi.org/10.1002/sce.21522

Maruthai, J. (2019). Stem Education in Malaysia: Barrier and challenges. Proceedings International Conference on Global Education VII "Humanising Technology For IR 4.0, 2017, 1-2.

Mashhadi, A., \& Woolnough, B. (1996). Cognitive mapping of advanced level physics students' conceptions of quantum physics. Conference on Educational Research (Australian Association for Research in Education), Singapore, 25.

Mashhadi, A., \& Woolnough, B. (1999). Insights into students' understanding of quantum physics: Visualizing quantum entities. European Journal of Physics, 20(6), 511-516. https://doi.org/10.1088/0143-0807/20/6/317

McKagan, S. B., Handley, W., Perkins, K. K., \& Wieman, C. E. (2007). A research-based curriculum for teaching the photoelectric effect. American Journal of Physics, 77(1), 87-94. https://doi.org/10.1119/1.2978181

McKagan, S. B., Handley, W., Perkins, K. K., \& Wieman, C. E. (2009). A research-based curriculum 

DOI: https://doi.org/10.47405/mjssh.v6i5.774

for teaching the photoelectric effect. American Journal of Physics, 77(1), 87-94. https://doi.org/10.1119/1.2978181

McKagan, S. B., Perkins, K. K., Dubson, M., Malley, C., Reid, S., LeMaster, R., \& Wieman, C. E. (2008). Developing and researching PhET simulations for teaching quantum mechanics. American Journal of Physics. https://doi.org/10.1119/1.2885199

McKillip, J. (1987). Need analysis: Tools for the human services and education. In Applied Social Research Methods Series, Volume 10. SAGE Publications, Inc.

Michelini, M., Ragazzzon, R., Santi, L., \& Alberto Stefanel. (2004). Implementing a Formative Module on Quantum Physics for Pre- Service Teacher Training. Quality Development in the Teacher Education and Training, 429-435.

Michelini, M., Santi, L., \& Stefanel, A. (2014). Teaching modern physics in secondary school. Proceedings of Science, 15-18-July(July), 1-10. https://doi.org/10.22323/1.224.0231

Michelini, M., Santi, L., Stefanel, A., \& Meneghin, G. (2002). A resource environment to introduce quantum physics in secondary school. Proceedings International MPTL-7.

MOE, K. P. M. (2016a). Buku Penerangan KSSM. Bahagian Pembangunan Kurikulum Kementerian Pendidikan Malaysia.

MOE, K. P. M. (2016b). Panduan Pelaksanaan Sains, Teknologi, Kejuruteraan, dan Matematik (STEM) dalam Pengajaran dan Pembelajaran. Kementerian Pendidikan Malaysia.

MOE, K. P. M. (2018). Dokumen Standard Kurikulum dan Pentaksiran KSSM Fizik Tingkatan 4 dan 5. Kementerian Pendidikan Malaysia.

MOE, K. P. M. (2019). Jumlah Pelajar Mengambil Sains,Teknologi, Kejuruteraan dan Matematik (STEM) Semakin Merosot. Sektor Pusat Dokumentasi Bahagian Perancangan Dan Penyelidikan Dasar Pendidikan, 02, 1-2.

Mohd Paris Saleh \& Saedah Siraj. (2016). Analisis Keperluan Pembangunan Model Pengajaran MPembelajaran Mata Pelajaran Sejarah Sekolah Menengah. Jurnal Kurikulum \& Pengajaran Asia Pasifik, Bil. 4(4), 12-24.

Moraga-Calderón, T., Buisman, H., \& Cramer, J. (2020). The Relevance of Learning Quantum Physics from the Perspective of the Secondary School Student: A Case Study. European Journal of Science and Mathematics Education, 8(1), 32-50.

MOSTI. (2013). National Policy On Science, Technology \& Innovation (NPSTI) Harnessing STI for Socio- Economic Transformation and Inclusive Growth (Issue July, p. 25).

MOSTI, M. of S. T. and I. (2017). Malaysian Science, Technology and Innovation Indicators Report 2016. In Ministry of Science, Technology and Innovation (MOSTI) Malaysian Science and Technology Information Centre (MASTIC).

Müller, R., \& Wiesner, H. (2002). Teaching quantum mechanics on an introductory level. American Journal of Physics. https://doi.org/10.1119/1.1435346

Murphy, S., MacDonald, A., Danaia, L., \& Wang, C. (2019). An analysis of Australian STEM education strategies. Policy Futures in Education, 17(2), 122-139. https://doi.org/10.1177/1478210318774190

Myhrehagen, H. V., \& Bungum, B. (2016). "From the cat's point of view": Upper secondary physics students' reflections on Schrödinger's thought experiment. Physics Education, 51(5), 1-11. https://doi.org/10.1088/0031-9120/51/5/055009

Nur Farhana Ramli, \& Othman Talib. (2017). Can Education Institution Implement STEM? From Malaysian Teachers' View. International Journal of Academic Research in Business and Social Sciences, 7(3), 2222-6990. https://doi.org/10.6007/IJARBSS/v7-i3/2772

Olsen, R. V. (2002). Introducing quantum mechanics in the upper secondary school: A study in Norway. International Journal of Science Education, 24(6), 565-574. https://doi.org/10.1080/09500690110073982

Park, W., Yang, S., \& Song, J. (2019). When Modern Physics Meets Nature of Science: The Representation of Nature of Science in General Relativity in New Korean Physics Textbooks. Science and Education, 28(9-10), 1055-1083. https://doi.org/10.1007/s11191-019-00075-9

Pearson, G. (2017). National academies piece on integrated STEM. Journal of Educational Research, 110(3), 224-226. https://doi.org/10.1080/00220671.2017.1289781

Polatdemir, E., Chin, Y. K., \& Martinez, J. C. (2004). Teachers' views on teaching quantum physics at junior college level Teachers' Views On Teaching Quantum Physics At Junior College Level. ERAS Conference, Singapore, November, 746-755. 
Porcaro, D. (2011). Applying constructivism in instructivist learning cultures. Multicultural Education \& Technology Journal, 5(1), 39-54. https://doi.org/10.1108/17504971111121919

Portillo, E. C., Look, K., Mott, D., Breslow, R., Kieser, M., \& Gallimore, C. (2020). Intentional Application of the Taba Curriculum Model to Develop a Rural Pharmacy Practice Course. INNOVATIONS in Pharmacy, 11(1), 21. https://doi.org/10.24926/iip.v11i1.2089

Ravaioli, G. (2019). Experiments and representations in quantum physics: Teaching module on the photoelectric effect and the Franck-Hertz experiment. Journal of Physics: Conference Series, 1286(1). https://doi.org/10.1088/1742-6596/1286/1/012032

Ravaioli, Giovanni, Olivia, L., \& Mathematics-physics, I. (2018). Accepting quantum physics: analysis of secondary school students' cognitive needs. ESERA 2017 Conference Dublin City, September 2019.

Richey, R. C., \& Klein, J. D. (2007). Design and Development Research (L. Akers \& A. Messina (eds.); 1st Editio). Lawrence Erlbaum Associates, Inc.

Ro, J. (2018). The meaning of teacher education in an exam-oriented education system: lessons from novice secondary teachers in Korea. Asia-Pacific Journal of Teacher Education, 47(4). https://doi.org/10.1080/1359866X.2018.1499013

Rodriguez, L. V. (2018). Teaching the wave- particle duality to secondary school students: an analysis of the dutch context (Issue December). University of Twente.

Satanassi, S., Levrin, O., \& Ravaioli, G. (2018). Quantum computers for high school: design of activities for an I SEE teaching module.

Sayer, R., Maries, A., \& Singh, C. (2017). Quantum interactive learning tutorial on the double-slit experiment to improve student understanding of quantum mechanics. Physical Review Physics Education Research, 13(1), 1-23. https://doi.org/10.1103/PhysRevPhysEducRes.13.010123

Schleich, W. P., Ranade, K. S., Anton, C., Arndt, M., Aspelmeyer, M., Bayer, M., Berg, G., Calarco, T., Fuchs, H., Giacobino, E., Grassl, M., Hänggi, P., Heckl, W. M., Hertel, I. V., Huelga, S., Jelezko, F., Keimer, B., Kotthaus, J. P., Leuchs, G., ... Zoller, P. (2016). Quantum technology: from research to application. Applied Physics B: Lasers and Optics, 122(5). https://doi.org/10.1007/s00340-016-6353-8

Shahali, E. H. M., Halim, L., Rasul, S., Osman, K., Ikhsan, Z., \& Rahim, F. (2015). Bitara-Stem ${ }^{\mathrm{TM}}$ training of trainers' programme: Impact on trainers' knowledge, beliefs, attitudes and efficacy towards integrated stem teaching. Journal of Baltic Science Education, 14(1), 85-95.

Shi, W. Z. (2013). The effect of peer interactions on quantum physics: A study from China. Journal of Baltic Science Education, 12(2), 152-158.

Siew, N. M., Amir, N., \& Chong, C. L. (2015). The perceptions of pre-service and in-service teachers regarding a project-based STEM approach to teaching science. SpringerPlus, 4(1), 1-20. https://doi.org/10.1186/2193-1801-4-8

Singh, C. (2008). Interactive learning tutorials on quantum mechanics. American Journal of Physics. https://doi.org/10.1119/1.2837812

Singh, C., \& Marshman, E. (2015). Review of student difficulties in upper-level quantum mechanics. Physical Review Special Topics - Physics Education Research. https://doi.org/10.1103/PhysRevSTPER.11.020117

Sokolowski, A. (2013). Teaching the photoelectric effect inductively. Physics Education, 48(1), 35-41. https://doi.org/10.1088/0031-9120/48/1/35

Soloway, E., Jackson, S. L., Klein, J., Quintana, C., Reed, J., Spitulnik, J., Stratford, S. J., Studer, S., Eng, J., \& Scala, N. (1996). Learning theory in practice: case studies of learner-centered design. Conference on Human Factors in Computing Systems - Proceedings, 189-196. https://doi.org/10.1145/238386.238476

Stadermann, H. K. E., \& Goedhart, M. J. (2020). Secondary school students' views of nature of science in quantum physics. International Journal of Science Education, 42(6), 997-1016. https://doi.org/10.1080/09500693.2020.1745926

Stadermann, H. K. E., Van Den Berg, E., \& Goedhart, M. J. (2019). Analysis of secondary school quantum physics curricula of 15 different countries: Different perspectives on a challenging topic. $\begin{array}{lllll}\text { Physical Review Physics Education Research, 15(1), } 10130 . & \end{array}$ https://doi.org/10.1103/PhysRevPhysEducRes.15.010130

Supurwoko, S., Cari, C., Sarwanto, S., Sukarmin, S., \& Suparmi, S. (2017). The effect of Phet Simulation media for physics teacher candidate understanding on photoelectric effect concept. 
International Journal of Science and Applied Science: Conference Series, 1(1), 33-39. https://doi.org/10.20961/ijsascs.v1i1.5108

Sutrini, C., Malgieri, M., \& de Ambrosis, A. (2019). Bubble: Experimenting with Feynman's sum over paths approach in the secondary school. Nuovo Cimento Della Societa Italiana Di Fisica C, 42(5), 1-10. https://doi.org/10.1393/ncc/i2019-19241-4

Taba, H. (1962). Curriculum development: Theory and practice.

Taber, K. S. (2005). Learning quanta: Barriers to stimulating transitions in student understanding of orbital ideas. Science Education, 89(1), 94-116. https://doi.org/10.1002/sce.20038

Tarng, W., Lee, C. Y., Lin, C. M., \& Chen, W. H. (2018). Applications of virtual reality in learning the photoelectric effect of liquid crystal display. Computer Applications in Engineering Education. https://doi.org/10.1002/cae.21957

Testa, I., Colantonio, A., Galano, S., Marzoli, I., Trani, F., \& Scotti di Uccio, U. (2020). Effects of instruction on students' overconfidence in introductory quantum mechanics. Physical Review $\begin{array}{llll}\text { Physics Education } & \text { Research, } & 10143 .\end{array}$ https://doi.org/10.1103/PhysRevPhysEducRes.16.010143

Thibaut, L., Ceuppens, S., De Loof, H., De Meester, J., Goovaerts, L., Struyf, A., Boeve-de Pauw, J., Dehaene, W., Deprez, J., De Cock, M., Hellinckx, L., Knipprath, H., Langie, G., Struyven, K., Van de Velde, D., Van Petegem, P., \& Depaepe, F. (2018). Integrated STEM Education: A Systematic Review of Instructional Practices in Secondary Education. European Journal of STEM Education, 3(1), 1-12. https://doi.org/10.20897/ejsteme/85525

Toma, R. B., \& Greca, I. M. (2018). The effect of integrative STEM instruction on elementary students' attitudes toward science. Eurasia Journal of Mathematics, Science and Technology Education, 14(4), 1383-1395. https://doi.org/10.29333/ejmste/83676

Wan Norhasma, W. H., \& Nurahimah, M. Y. (2019). 'SKPMg2' (Standard 4) as tools to upgrade teachers' teaching quality. Journal of Educational Research and Indigeneous Studies.

White, D. W. (2014). What is STEM education and why is it important? Florida Association of Teacher Educators Journal, 1(14), 1-10.

Yaakob, M. N. (2016). Pembangunan Model Kurikulum M-Pembelajaran Teknologi Dalam Pengajaran Dan Pembelajaran Di Ipg Doctor of Philosophy. Universiti Utara Malaysia (UUM).

Zaher Atwa, Rosseni Din, \& Muhammad Hussin. (2016). Effectiveness of flipped learning in physics education on palestinian high school students' achievement. Journal of Personalized Learning, 2(1), 73-85.

Zollman, D. (1999). Research on teaching and learning quantum mechanics. Annual Meeting of National Association for Research in Science Teaching, 46. 